\title{
What is Metabolic Surgery? To Whom and When Should It Be Applied?
}

\author{
Metabolik Cerrahi Nedir? Kime ve Ne Zaman Yapılmalıdır?
}

\author{
Fatih Ciftci \\ Istanbul Gelisim University, Istanbul, Turkey
}

\begin{abstract}
Metabolic syndrome is a cluster of cardiometabolic risk factors that cause some complications. Each component of the syndrome needs to be treated. For this purpose, anti-hypertensive, anti-diabetic, and anti-lipidemic agents are used, but weight control plays a key role in treatment. Exercise, reduction of daily calories with diet and increasing physical activity play a role in the control of body weight. Various medical treatments have been tried, but they have not been very effective. The most effective way is still surgery. Although there is no definite accepted definition of metabolic surgery, it can be defined as surgical interventions to treat metabolic syndrome.

The general perception in bariatric surgery is that type 2 diabetes enters remission due to patients' weight loss. After the operation in these patients, blood sugar control has been shown to be achieved while patients are still in the hospital. It has been understood that the gastrointestinal system plays an essential role in glucose homeostasis, and its mechanisms have been tried to be revealed. The foregut hypothesis and the hindgut hypothesis have been suggested.
\end{abstract}

A hindgut surgery like a duodenal switch has been shown to improve insulin sensitivity and glucose homeostasis without causing a hyperinsulinemic response compared to a foregut surgery like a gastric bypass. Surgeries that modulate the hindgut have more potential to disrupt the absorption of vitamins and minerals than foregut surgeries.

To prevent this, the transit bipartition technique has been developed in recent years. As a result, various methods have been used in metabolic surgery. The choice of a surgical technique should be specific to the patient.

Key words: metabolic surgery; timing; type 2 diabetes mellitus

\section{ÖZET}

Metabolik sendrom bazı komplikasyonlara neden olan kardiyometabolik risk faktörleri demetidir. Sendromu olușturan her bileșen tedavi edilmelidir. Bunun için antilipidemik, antidiyabetik, antihipertansif, ilaçlar kullanılır fakat tedavideki kilit rolde kilo kontrolü oynar. Vücut ağırlığının kontrolünde egzersiz, diyetle günlük alınan kalorinin azaltılması ve fiziksel faaliyetlerin artırılması rol oynar. Değișik tıbbi tedavilerlede deneme yapılmıș olup çok bașarılı olunamamıștır. Hala en etkin yol cerrahi seçenektir. Kesin kabul edilen tanımı olmamakla beraber metabolik cerrahi, metabolik sendromu tedavi etmek için yapılan cerrahi müdahaleler olarak tarif edilebilir.

Genel algı bariatrik cerrahi geçiren hasta kișilerin kilo vermeyle ilișkili tip 2 diyabet hastalığının remisyona girmesidir. Ameliyat sonrası bu hastalar hastanede yatarken kan șeker değerlerinin düzelmeye bașladığı görülmüștür. Kan glukozu dengelenmesinde gastrointestinal sistemin önemli rol aldığı anlașılınca, mekanizmasının ortaya çıkması için çalıșmalar yapılmıștır. Ön ve arka barsak hipotezleri ortaya atılmıștır.

Arka barsak ameliyatı olan Duodenalswitch'in ön barsak ameliyatı olan gastrik by-pass'a göre hiperinsülinemik cevaba neden olmadan glukoz dengesini ve insülin duyarlılığında iyileșme sağladığı ortaya konmuștur. Arka barsak modulasyonu yapılan ameliyatlar, ön barsak modülasyonu yapılan ameliyatlara göre mineral-vitamin dengesini daha çok bozma eğilimindedir. Son zamanlarda bunu önlemek için transit bipartisyon ameliyatı geliștirilmiștir. Sonuçta metabolik cerrahi ameliyatlarında değișik teknikler tercih edilmektedir. Yapılacak ameliyat yönteminin kișiye özel olması gerektir.

Anahtar kelimeler: metabolik cerrahi; zamanlama; tip 2 diyabet

$\mathrm{T}$ he adipose tissue accumulated in the body due to irregular and uncontrolled nutrition causes various diseases. These can include hepatosteatosis, hypertension (HT), cardiovascular diseases, osteoarthrosis, type 2 diabetes mellitus (T2DM), alveolar ventilation deficiency, cerebrovascular diseases, hypertriglyceridemia, and varicose veins. Some of the risk factors that occur mainly due to insulin resistance play a role in the development of cardiovascular diseases. This association, which was first emphasized in 1988 and previously called. Syndrome X, is called metabolic syndrome nowadays. Among them, there are abdominal obesity, increased blood pressure, T2DM, and lipid disorders. Insulin resistance results in 
decreased glucose uptake into cells in various tissues, primarily skeletal muscle, increased lipolysis in adipose tissue, and decreased gluconeogenesis in the liver. Obesity, sedentary lifestyle, smoking, low birth weight, and perinatal malnutrition have also been associated with the development of insulin resistance. Adipose tissue and hormones secreted from this tissue, hypothalamus-pituitary-adrenal axis disorders, advancing age, genetic and environmental causes also contribute to the development of insulin resistance ${ }^{1}$. The frequency of metabolic syndrome increases with increasing age and body weight of the studied population and shows social variability. According to the results of the Turkish Metabolic Syndrome Research conducted in 2004 in our country, the frequency of metabolic syndrome in adults aged 20 years and older was found to be $35 \%^{2}$.

The definition of metabolic syndromerefers to the coexistence of at least three of the following medical conditions: abdominal obesity, high blood pressure, high blood sugar, high serum triglyceride level, and low high-density lipoprotein level. However, different study groups can use different definitions (Table 1). The data obtained in the metabolic syndrome research study is based on the evaluations made by accepting the waist circumference as $102 \mathrm{~cm}$ in men and $88 \mathrm{~cm}$ in women. A higher frequency of metabolic syndrome could be detected if the $94-88 \mathrm{~cm}$ accepted today is considered a limit.

Metabolic syndrome, of course, leads to life-threatening complications. Therefore, each component of the syndrome needs to be treated. For this purpose, anti-hypertensive, anti-diabetic, and anti-lipidemic agents are used, but weight control plays a key role in treatment because the production of substances such as TNF-alpha, adiponectin, resistin, and PAI-1 induced by increased visceral fat, and the complex and not yet fully illuminated inflammatory processes caused by them underlie the metabolic syndrome. Although the ideal way to control weight is to reduce the daily calorie intake and increase physical activity with diets and exercises, unfortunately, there is not much success in today's society.

For this purpose, various medical treatments have been tried, but very effective results have not been achieved. Nowadays, the most effective way to treat obesity is still bariatric surgery. The definition of bariatric surgery is derived from the Greek words baros (weight) and iatricos (treatment). The concept has evolved into metabolic surgery over time due to the positive effects of bariatric surgery on weight control as well as diabetes, hypertension, and blood lipid profile. Although there is no precise definition of metabolic surgery, it can generally be defined as surgical interventions to treat metabolic syndrome.

The studies that started in the field of bariatric surgery in the $1950 \mathrm{~s}$ enabled the introduction of the frequently used surgical methods when the 80 s were reached and the spread of these methods with the introduction of laparoscopy in gastrointestinal surgery in the 90s. The general perception during this period was that type 2 diabetes entered remission due to patients' weight loss. However, in a study conducted in $1995^{3}$, the whole perception began to change when they published studies showing that patients with type 2 diabetes who underwent a gastric bypass had blood glucose control achieved while the patients were still in the hospital, that is, before losing significant weight. Since then, it has been understood that the gastrointestinal tract plays a vital role in glucose homeostasis, and its mechanisms have been tried to be revealed. Gastric bypass surgery has been shown to divert food from the duodenum, reducing glucagon release with anti-insulin activity. Beyond that, the early access of foods to the lower parts of the small intestine stimulates the release of incretins, and it is known that glucagon-like peptide-1 (GLP-1) and gastric inhibitory polypeptide (GIP) with typical incretin activity have trophic effects on pancreatic beta cells and increase insulin secretion.

At this point, two different views emerged. According to the first view: "disabling the duodenum improves type 2 diabetes (the foregut hypothesis), which occurs as a result of disruption of the balance between incretins and peptides with anti-incretin activity in the body" The second view is that the increase in the production of GLP-1 released from the L cells with the early arrival of the food in the terminal ileum plays a major role in the control of diabetes (the hindgut hypothesis) ${ }^{5}$. Although the place of surgery remains controversial for the treatment of T2DM, which has been tried to be treated with insulin despite the hyperinsulinemic condition for decades, at the point we have reached today, even the American Diabetes Association recommends metabolic surgery with a high level of evidence (category A) in candidates eligible for surgery even for the treatment of T2DM regardless of the level of glycemic control if the body mass index (BMI) is $40 \mathrm{~kg} / \mathrm{m}^{2}$ or more, and in patients with a BMI of $35-39.9 \mathrm{~kg} / \mathrm{m}^{2}$ when hyperglycemia cannot be adequately controlled despite the lifestyle changes and optimal medical treatment ${ }^{6}$. Even in the same guideline, it was emphasized that metabolic surgery could be considered in cases 
Table 1. Metabolic syndrome definitions

\begin{tabular}{|c|c|c|c|c|}
\hline & IDF & NCEP & WHO & AACE \\
\hline \multirow[t]{2}{*}{ Diagnosis } & If the blood glucose level is & $\begin{array}{l}\text { If } 3 \text { out of the } 5 \text { criteria below } \\
\text { are present }\end{array}$ & If the blood glucose level is & \\
\hline & $\begin{array}{l}\text { abnormal and if at least two of } \\
\text { the following are present }\end{array}$ & & $\begin{array}{l}\text { abnormal and if at least two of } \\
\text { the following are present }\end{array}$ & Shows risk factors \\
\hline \multirow[t]{2}{*}{ Glycemia } & $\begin{array}{l}\text { Fasting blood sugar of } \\
100-125 \mathrm{mg} / \mathrm{dL} \text { or T2DM }\end{array}$ & & Glucose intolerance, T2DM & $\begin{array}{l}\text { Fasting blood sugar of } \\
100-125 \mathrm{mg} / \mathrm{dL} \text { or }>140 \mathrm{mg} / \mathrm{dL}\end{array}$ \\
\hline & & Blood sugar of $100-125 \mathrm{mg} / \mathrm{dL}$ & or insulin resistance & at the 2nd hour after OGTT \\
\hline \multirow[t]{4}{*}{ Abdominal obesity } & Waist circumference: & Waist circumference: & $\mathrm{BMI}>30$ and & $\mathrm{BM} \geq 25$ and \\
\hline & $\geq 94 \mathrm{~cm}$ in men & $>102 \mathrm{~cm}$ in men & Waist-to-hip ratio: & Waist circumference: \\
\hline & $\geq 80 \mathrm{~cm}$ in women & $>88 \mathrm{~cm}$ in women & $>0.9$ in men & $>102 \mathrm{~cm}$ in men \\
\hline & & & $>0.85$ in women & $>88 \mathrm{~cm}$ in women \\
\hline \multirow[t]{4}{*}{ Lipid profile } & $\mathrm{T} \mathrm{G} \geq 150 \mathrm{mg} / \mathrm{dL}$ or & $\mathrm{T} \mathrm{G} \geq 150 \mathrm{mg} / \mathrm{dL}$ or & $\mathrm{T} \mathrm{G} \geq 150 \mathrm{mg} / \mathrm{dL}$ or & $\mathrm{T} \mathrm{G} \geq 150 \mathrm{mg} / \mathrm{dL}$ or \\
\hline & $\mathrm{HDL}$ & HDL & HDL & $\mathrm{HDL}$ \\
\hline & $<40$ in men & $<40$ in men & $<35$ in men & $<40$ in men \\
\hline & $<50$ in women & $<50$ in women & $<39$ in women & $<50$ in women \\
\hline \multirow[t]{3}{*}{ Hypertension } & $\begin{array}{l}\text { Being treated for systemic } \\
\text { arterial HT or Blood Pressure }\end{array}$ & $\begin{array}{l}\text { Blood Pressure of } \\
\geq 130 / 85 \mathrm{mmHg}\end{array}$ & $\begin{array}{l}\text { Being treated for systemic } \\
\text { arterial HT or Blood Pressure }\end{array}$ & $\begin{array}{l}\text { Blood Pressure of } \\
\geq 130 / 85 \mathrm{mmHg}\end{array}$ \\
\hline & of $\geq 130 / 85 \mathrm{mmHg}$ & & of $\geq 160 / 90 \mathrm{mmHg}$ & \\
\hline & & & Microalbuminuria $\geq 20 \mathrm{mcg} / \mathrm{dk}$ & \\
\hline
\end{tabular}

OGTT, oral glucose tolerance test; T2DM, Type 2 diabetes mellitus; TG, triglyceride; HDL, high (density) lipoprotein; NCEP, US national cholesterol education program; IDF, international diabetes federation; WHO, World Health Organization; AACE, American College of Endocrinology / American Association of Clinical Endocrinologists.

when hyperglycemia could not be controlled despite oral and injectable treatments even in those with a BMI of $30-34.9 \mathrm{~kg} / \mathrm{m}^{2}$ (category B).

However, the incident is not limited to the incretin activity, obese individuals, or T2DM. Important pathophysiological mechanisms that mediate the beneficial effects of metabolic surgery include multi-organ insulin sensitivity (hepatic and skeletal muscle), betacell function, changes in the bile acid composition and flow, and increased metabolic activity in brown adipose tissue. Furthermore, the increase in microbial diversity in the intestine and changes in the ratio of some specific bacterial species may contribute to this metabolic activity ${ }^{5-7}$. There are studies reporting that complete remission was achieved in T2DM in up to $85 \%$ of patients after metabolic surgery, even in individuals with a BMI of $28-35 \mathrm{~kg} / \mathrm{m}^{2}$, and that the rates of patients using anti-hypertensive and anti-lipidemic agents decreased from $38 \%$ to $11 \%$ and from $56 \%$ to $4 \%{ }^{8}$. One of the problems is that the metabolic effect of each type of surgery is different from each other, and individual differences between patients can affect the results. For example, a hindgut surgery like a duodenal switch has been shown to improve insulin sensitivity and glucose homeostasis without causing a hyperinsulinemic response compared to a foregut surgery like a gastric bypass ${ }^{9}$. Of course, surgeries that modulate the hindgut have more potential to disrupt the absorption of vitamins and minerals than foregut surgeries. In order to prevent this, in recent years, methods for ensuring the effectiveness of the posterior intestine are being tried in the form of transit bipartition without preventing contact of the food with any small intestinal tissue. In order to prevent this, in recent years, methods for ensuring the effectiveness of hindgut surgeries, in the form of transit bipartition, without preventing contact of food with any small intestine tissue, have been tried.

The difference between metabolic surgery and traditional bariatric surgery is mainly based on the characteristics of patients. Patients who prefer bariatric surgery are typically young, predominantly female, and patients with a relatively lower T2DM prevalence than patients with a similar BMI. On the contrary, although patients who are 
considered eligible for metabolic surgery are often obese, they are older, predominantly male, and have more severe T2DM and cardiovascular diseases ${ }^{10,11}$. It is not surprising that these differences have an impact on surgical outcomes (such as diabetes remission rates and cost-effectiveness) and patient care issues. Traditional bariatric surgery is perceived as an attempt to reduce the risk of future diseases (such as obesity-related metabolic or cardiovascular complications) rather than treating existing diseases. This false perception is observed in many bariatric surgery guidelines nowadays, but it should not be forgotten that T2DM is a progressive disease that causes an increased risk for cardiovascular diseases and microvascular complications. Furthermore, the rate of metabolic recovery after surgery in patients with T2DM is related to the duration of T2DM. The shorter the duration of the disease is, the better the outcomes are ${ }^{12-14}$. This means reduced success and cost-effectiveness if surgical treatment is unnecessarily delayed. The patient acceptance criteria used for bariatric surgery have low significance for metabolic surgery. For example, the BMI cannot be considered as a stand-alone criterion for metabolic surgery because the BMI is neither a standard diagnostic parameter nor a measure that determines the severity of T2DM. For this reason, it was concluded that metabolic surgery should be considered even in Class I obese individuals, in which diabetic control is difficult, at the 2 nd Diabetes Surgery Summit, where $75 \%$ of the participants consisted of diabetologists or endocrinologists ${ }^{15-17}$.

\section{Conclusion}

Definitions related to bariatric surgery are shifting towards metabolic surgery due to the positive effects of the method on metabolic status. The bariatric surgery procedures considered as the most effective way of treating obesity are regarded as the most effective methods in the treatment of T2DM nowadays. Due to differences in the effectiveness of these methods, there is a need for patient-specific method choices rather than creating treatment protocols indexed to a nonstandard parameter such as BMI.

\section{References}

1. Janković D, Wolf P, Anderwald CH, Winhofer Y, PromintzerSchifferl M, Hofer A, et al. Prevalence of endocrine disorders in morbidly obese patients and the effects of bariatric surgery on endocrine and metabolic parameters. Obes Surg 2012;22(1):62-9.
2. Elshaer M, Hamaoui K, Rezai P, Ahmed K, Mothojakan N, Al-Taan O. Secondary Bariatric Procedures in a High-Volume Centre: Prevalence, Indications and Outcomes. Obes Surg 2019;29(7):2255-2262.

3. Cottam S, Cottam D, Cottam A. Sleeve Gastrectomy Weight Lossand the preoperative and postoperative predictors: A systematic Review. Obes Surg 2019;29(4):1388-1396.

4. Worm D, Madsbad S, Hansen DL. Metabolic Healthy in severely obese subjects: A Descriptive study. Metab Syndr Relat Disord 2019;17(2):115-119.

5. Wang L, Wang J, Jiang T. Effect of Laparoscopic Sleeve Gastrectomy on Type 2 Diabetes Mellitus in patients with Body Mass Index less than $30 \mathrm{~kg} / \mathrm{m} 2$. ObesSurg 2019;29(3):835-842.

6. Rubino F, Shukla A, Pomp A, Moreira M, Ahn S. M, Dakin $\mathrm{G}$, et al. Bariatric, metabolic, and diabetes surgery: what's in a name? Ann Surg 2014;259:117-22.

7. Rubino F, Forgione A, Cummings DE, et al. The mechanism of diabetes control after gastrointestinal bypass surgery reveals a role of the proximal small intestine in the pathophysiology of type 2 diabetes. AnnSurg 2006;244:741-9.

8. Nora M, Guimarães M, Almeida R, Martins P, Gonçalves G, Santos M, et al. Excess Body Mass Index Loss Predicts Metabolic Syndrome Remission After Gastric Bypass Diabetol Metab Syndr 2014 2;6(1):1.

9. Cazzo E, Gestic MA, Utrini MP, Machado RR, Geloneze B, Pareja JC, et al. Impact of Roux-en-Y-Gastric Bypass on Metabolic Syndrome and Insulin Resistance Parameters. Diabetes Technol Ther 2014;16(4):262-5.

10. Li JF, Lai DD, Ni B, Sun KX. Comparison of Laparoscopic Roux-en-Y Gastric Bypass With Laparoscopic Sleeve Gastrectomy for Morbid Obesity or Type 2 Diabetes Mellitus: A Meta-Analysis of Randomised Controlled Trials. Can J Surg 2013;56(6):158-64.

11. Aftab H, Risstad H, Søvik TT, Bernklev T, Hewitt S, Kristinsson JA, et al. Five-year Outcome After Gastric Bypass for Morbid Obesity in a Norwegian Cohort. Surg Obes Relat Dis 2014 J; 10(1):71-8.

12. Gloy VL, Briel M, Bhatt DL, Kashyap SR, Schauer PR, MingroneG, et al. Bariatric surgery versus non-surgical treatment for obesity: a systematic review and meta-analysis of randomised controlled trials. BMJ 2013 22;347: f5934.

13. Desiderio J, Trastulli S, Scalercio V, Mirri E, Grandone I, Cirocchi R, et al. Effects of laparoscopic sleeve gastrectomy in patients with morbid obesity and metabolic disorders. Diabetes Technol Ther 2013;15(12):1004-9.

14. Neff KJ, le Roux CW. Bariatric Surgery: The indications in Metabolic Disease. Neff KJ, le Roux CW. DigSurg 2014;31(1):6-12.

15. Williams S, Cunningham E, Pories WJ. Surgical Treatment of metabolic syndrome Med Princ Pract 2012;21(4):301-9.

16. Gass M, Beglinger C, Peterli R. Metabolic Surgery-Principles and Current concepts Langenbecks Arch Surg 2011;396(7):949-72.

17. Sabench Pereferrer F, Hernàndez Gonzàlez M, Del Castillo Déjardin D. Experimental Metabolic Surgery: Justification and Technical Aspects Obes Surg 2011;21(10):1617-28. 